\title{
Chapter 15 \\ Industry-Led Training \\ and Apprenticeships: The New Zealand \\ Model
}

\author{
Josh Williams
}

Like many vocational education systems, New Zealand's systems for workplace training and apprenticeships have evolved in response to changes in industries and also through government-led reviews and initiatives. However, the fundamentals of New Zealand's current approach have been remarkably stable since first introduced in 1992. Things may be all about to change, in light of proposed large-scale reforms of New Zealand's vocational sector.

This article sets out some of its key features and the policy choices that led to the present system. It attempts to describe some of the lessons we have learned; the things we think have worked and are working; and finally, some forward-looking considerations as New Zealand-as everywhere else-looks at how well its vocational education system is set up for the challenges of the "future of work."

In particular, I want to set out the key policy "ingredients" that have sustained our system for the last 25 years-including the functions of Industry Training Organizations (ITOs), employment structures, and qualifications policies that support our nationally recognized training system.

\section{Issues and Challenges}

New Zealand has had a long history of apprenticeship training (at least by New Zealand standards). Through the middle of the twentieth century in particular, apprenticeship was seen as a core pathway-especially for males - to enter the workforce straight from school. As the New Zealand economy was going through radical change

\section{J. Williams (凶)}

Chief Executive of the Industry Training Federation, Wellington, New Zealand e-mail: josh@itf.org.nz 
through the second half of the 1980s, so too the education system was being reviewed and reconsidered in an attempt to align education with emerging economic realities.

In 1986, a Department of Labour Green Paper on Vocational Education outlined a number of the elements that would arise in industry training reforms 6 years later. Training arrangements were described as "haphazard and uncoordinated." A national certification system was called for, based on competency.

Further impetus for reform was provided in 1988 through a Ministerial Committee on Education and Training. Its report-Learning for Life-foresaw and promoted the notion of lifelong learning, stating that learners should engage in a comprehensive and seamless tertiary education system. That seamlessness extended into people's working lives, and the tertiary education system extended into workplaces. So while New Zealand already had a history of apprenticeships, the new thought was to connect this with the formal post-school education system.

Meanwhile, institutional vocational education was beset by concerns about supply-side capture - under a model that rewarded participation, providers would offer what students wanted to do, not what industry needed them to do. Government ministers of the time were impressed by the industry ownership and control they observed in systems like in Germany, and the emergence of competency-based frameworks such as in Scotland.

These contextual factors culminated in a core policy choice: government ceded to industry the role to set occupational standards and make the arrangements for people working in industries to achieve them. It was a demand-side solution: Industry wins if the skills are right, and industry loses if the skills are wrong, so let industry determine its needs and work with its employers on the best way to train.

The manifestation of this policy choice was the ITOs. These are industry-owned and governed entities, formed up from enterprises, that apply to the Government for recognition as the standard-setting body for an industry or set of industries. In the modern sector, most ITOs are entities in their own right-for the most part not-forprofit incorporated societies - though they have also been run as arms of industry associations.

Similar to what other countries have variously called "skills councils," "industry councils," or "sector councils," ITOs' core role is to work with industry to develop occupational standards (commonly referred to as unit standards), and develop training and assessment resources in support of their achievement.

\section{Arranging Training}

But New Zealand's ITOs have a second role, and quite a unique feature: They work with industry employers on arranging training, including the use of government subsidies to purchase training from providers, usually to complement on-the-job training. This provides a direct lever for industry to invest in provision that meets its needs, and not to invest in that which does not. An ITO can seek training subsidies through 
funding agencies in much the way that our public and private training providers do, however there are some key differences:

- Industry training is co-funded. Government subsidies are contingent on an ITO demonstrating, on an annual basis, that it is receiving $30 \%$ of its income directly from industry. This is a core check-and-balance in the system-an ITO proves that it is supported by its industry through industry financial contribution. Its ability to maintain government recognition and resourcing is contingent on showing this.

- Government subsidy rates for industry training are much lower than for providerbased tuition. The per-place funding for industry trainees and apprentices in New Zealand is, generally speaking, one-half to two-thirds lower than the per-place funding for education providers. This is because government is not paying for teaching, or classrooms, or operational overheads. The funding ITOs receive is to manage training, which covers the purchasing of off-job training components, but everything else too including standards setting, resource development, assessment, and quality assurance processes.

What is arranging? In effect, an ITO works with an employer and an apprentice or trainee to establish a training agreement. This training agreement is formally part of an employment agreement and sets out the program of training-on-the-job, offjob, or usually both - that will allow the trainee or apprentice to complete a national qualification: the New Zealand Qualifications Framework (NZQF).

The ITO then, through permutations of advisory services, pastoral care, and assessment services, supports both the employer and the trainee to achieve the standards and qualifications.

The second element of the "arranging" role is what it is not: It does not include, and legislatively prohibits, the direct delivery of training. It was - certainly in the design phase in the early 1990s - seen as a conflict of interest to be both the standard-setting body and the deliverer of training. Fast forwarding 27 years, this is difficult in practice to define. The rise of digital learning blurs the distinctions between teaching and learning and assessment, and what is meant by delivery. Second, across education, the importance of pastoral care and wrap-around support to learners is seen as critical to their success, irrespective of setting. Finally, it seems peculiar that both designing and delivering a program is seen as a conflict of interest when it comes to workplace learning, but not in institutional settings.

Before moving on to examples of such arrangements, it is worth making some observations about what 25 years of a "bottom-up" and industry-led system has looked like-in particular for the lessons we have learned, but also to illustrate some in-principle strengths of the system.

The first intrinsic advantage is common to all work-based learning: The trainee has been placed in the labor market already, so we have already achieved the outcome of ensuring there is a match between the learning and a labor market need-the right skills, in the right place, at the right time.

Aligned with that, an industry-led system ensures close linkages between the skills being developed and the skills being deployed - they are one and the same. A trainee may not yet be the most productive worker, and training him or her also represents 
a cost to the firm that may not be the long-term beneficiary of his or her skill, but the real economy sees at least some return through training a worker through a real employer, in contrast with an institutional (only) approach, which is rather more "hit and hope" in terms of whether the skill development will match its eventual application in industry, if the learner is employed in that industry at all.

A second advantage of the industry-led approach is that it allows each industry to morph and evolve its arrangements to suit itself. This applies to both the mix of training modes, and the approach to assessment. The mix of on- and off-job learning differs according to industry's wishes. For example, in New Zealand, a plumbing apprentice undertakes around $75 \%$ of the apprenticeship through block courses offthe-job. By comparison, a carpentry apprentice achieves $95 \%$ of the apprenticeship on-the-job. Still other industries-particularly those in services sectors, e.g., retail, hospitality, are $100 \%$ on-the-job.

While this may look a bit messy from the outside, it actually represents a necessary flexibility, and represents the revealed preferences of those industries about the methods and means of training that work for the industry. While each industry has developed its typical case, there is also an element where industry training in New Zealand is necessarily bespoke-in an economy where $95 \%$ of enterprises have five or fewer employees, the scope and size of any one employer necessitates a different approach to the mix of digital and on- and off-job approaches.

The connection between standard setting and arranging also creates a critically important feedback loop that benefits both activities. The day-to-day engagement with real employers through supporting trainees forms a critical input to standard setting, and what is termed skills leadership — to identify what is emerging and what is obsolescing.

Administering the traineeship or apprenticeship from the industry side also provides a demand-side "check and balance" over what vocational providers deliver and teach, to the extent that ITOs can use their purchasing power over block courses to determine this.

\section{Standard Setting}

New Zealand's approach, like many other countries, invites ITOs as standard-setting bodies to establish and register occupational standards. These are evaluated and registered by our single awarding and quality assurance body, the New Zealand Qualifications Authority. The unit standards were originally components of qualifications, when the qualifications framework was entirely standards-based. In large part now the unit standards are one of several possible approaches to assessment and provide one possible pathway to a qualification.

The lesson of history would suggest that ITOs were more rather than less prescriptive in their approach to standard setting, particularly early in their history, and particularly when there were more ITOs than there are now. However, the trend in the present day is toward newer and more flexible ways to assess and recognize skills. One example of this is microcredentials, which offer a modular and augmentable way to add and recognize skills through quality-assured credentials but not necessarily 
with the need or expectation to achieve full qualifications. This is seen as a fit-forpurpose approach in a fast-moving industry skills landscape, though it might also be remembered that the good old unit standard was invented for exactly these reasons and offered all those advantages, all those years ago.

The structure of the industry training and apprenticeship sector itself has also changed and evolved; throughout its history the number of ITOs has changed, and areas of industry coverage have been added and shifted around. The number of ITOs peaked at 56 just 4 years following the 1992 introduction, then settled to around 40 for most of the 2000s, then significantly consolidated in response to a governmentled review of the sector between 2010 and 2014. However, most of these moves were generated by changes within industries, or to resolve areas of overlap. Since 2014, there have been 11 recognized ITOs.

A growing area for New Zealand's ITOs has been the school-to-work transition. While in the past, apprenticeship straight from school was a well-trodden pathway, this is no longer the case, with only $6 \%$ of New Zealand's school leavers having a formal ITO training agreement within 12 months of leaving school. Our average apprentice is 26 years old, with well over half of them already achieving postschool qualification, including at the degree level. In one sense this is a fine thing, since it reflects lifelong learning in action. People are continuing their engagement with the education system as part of their working life. On the other hand, it also suggests a need for better promotion of work-based options and pathways to school through broadening career information and education.

The Industry Training Federation (ITF) has worked closely with the Government over the last several years to implement a color-coded framework of "vocational pathways" that identify how learnings in traditional school subjects are recommended for further study and work possibilities in major economic sectors. The vocational pathways have also underpinned program design for several "interface" initiatives, wherein students spend part of their time learning in a tertiary provider or workplace while still enrolled at school. In the best examples, these schemes resemble the dual training approach more typically associated with countries in Western Europe. In the worst examples, these schemes are perceived as second-chance options for less academically inclined students. In the main, however, there is increasing recognition that senior-level schooling in New Zealand needs to move to a broader exploration of pathways and opportunities beyond school, and the vocational pathways are providing a useful framework to help students, teachers, and employers navigate the space and offer relevant and coherent education.

New Zealand, like many countries, is absorbed in debates about the future of work. Technology change, automation, dynamic careers, and an aging workforce necessitate a rethink of industrial age approaches to skills development. We know that in longer and multifaceted careers, people cannot solely be "preloaded" with pre-employment education. They will need to upskill over time, increasingly through their employers. At the same time, we need to ensure that training systems operate at the industry level, so that workers are portable and resilient in such dynamic labor markets. There is much to do to ensure that qualifications are modular, and 
maintain currency, but ultimately, if people are to make successful transitions in such a workforce, the ability to prove their skills to their next employer will remain critical.

The critical element of this is employer engagement. Employers need to be willing and supported to train people for their industry, not just for their job right now. That is a sacrifice and is perceived as a cost, even as any number of return on investment studies show the bottom-line benefits to firms of training - at least in the medium term, and certainly to the industry and economy as a whole.

ITOs therefore work hard to ensure that training materials and systems are as user friendly to employers as possible. The advantages of offering a firm a qualityassured training infrastructure need to outweigh the perceived costs of compliance and/or costs associated with training as part of the national system; otherwise an employer will not participate. The ITF has consistently argued that we should do more to support more New Zealand employers to join the system, preferably through encouragement, support, and direct incentives.

As this article is being prepared, the vocational education crystal ball is very murky, while the stakeholders of New Zealand's vocational education system await government decisions over a comprehensive reform of the vocational education and training sector.

The reforms seek a more unified and coherent system, particularly between the provider- and work-based parts of the present system. The reforms are driven by financial pressures in the public vocational providers, but also a broader sense that the vocational sector is responsible for persistent skills shortages, and/or skills mismatches, as experienced by industries and the business community.

While its high-level aims are laudable, the proposal as consulted will decouple standard setting (to be performed by new industry skills bodies) and training: The management and support of industry trainees and apprentices will become the responsibility of vocational providers, rather than industry training organizations.

While all stakeholders agree that the system can be more collaborative and coherent, many, including this author, are seriously concerned that the strengths and advantages of our industry-led system will be negatively affected. I hope I am wrong and time will tell!

Irrespective of what happens, over the last 27 years we have seen a largely stable and successful industry training system. It has been buffeted at times by various external forces, but it has much to commend as a demand-led solution to workforce skills development. Its recent improvements in participation and performance are pleasing, and through partnering with private sector firms its cost effectiveness to government is compelling. We have learned a lot along the way, and suspect other countries could benefit from looking at the New Zealand approach of the last 27 years, including its present debates.

Link to the presentation materials: https://events.development.asia/materials/201 51201/new-zealand-s-industry-training-and-apprenticeship-system-public-private. 


\section{Further Reading}

Industry Training Federation of New Zealand. (2003). A Brief History of Funding for Industry Training 1989-2002.

Industry Training Federation of New Zealand. (2016). Creating real futures together: New Zealand's industry training and apprenticeship system. http://www.itf.org.nz/sites/default/files/publicati ons/CRFT_web.pdf.

Ministry of Education, New Zealand. (2012). History of Industry Training. https://education.govt. nz/assets/Documents/Ministry/consultations/Review-of-industry-training/HistoryOfIndustryT rainingFINAL.pdf.

Ministry of Education, New Zealand. (2019). Reform of Vocational Education: Consultation Discussion Document. https://conversation.education.govt.nz/assets/RoVE/Reform-of-Vocational-Edu cation-Consultation-Discussion-Document.pdf.

Murray, N. (2001). A history of apprenticeship in New Zealand. Unpublished Master of Social Science thesis, Lincoln University, Canterbury.

The views expressed in this Chapter are those of the authors and do not necessarily reflect the views and policies of the Asian Development Bank (ADB) or its Board of Governors or the governments they represent.

ADB does not guarantee the accuracy of the data included in this Chapter and accepts no responsibility for any consequence of their use. The mention of specific companies or products of manufacturers does not imply that they are endorsed or recommended by ADB in preference to others of a similar nature that are not mentioned.

By making any designation of or reference to a particular territory or geographic area, or by using the term "country" in this Chapter, ADB does not intend to make any judgments as to the legal or other status of any territory or area.

This work is available under the Creative Commons Attribution 3.0 IGO license (CC BY 3.0 IGO) https://creativecommons.org/licenses/by/3.0/igo/. By using the content of this Chapter, you agree to be bound by the terms of this license. For attribution, translations, adaptations, and permissions, please read the provisions and terms of use at https://www.adb.org/terms-use\#openac cess.

This CC license does not apply to non-ADB copyright materials in this Chapter. If the material is attributed to another source, please contact the copyright owner or publisher of that source for permission to reproduce it. ADB cannot be held liable for any claims that arise as a result of your use of the material.

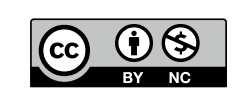

